\begin{tabular}{|l|l|l||}
\hline \multicolumn{2}{|c|}{ PublisherInfo } \\
\hline \hline PublisherName & $:$ & BioMed Central \\
\hline \hline PublisherLocation & $:$ & London \\
\hline \hline PublisherImprintName & $:$ & BioMed Central \\
\hline \hline
\end{tabular}

\title{
Effects of increasing MAP on tissue perfusion
}

\begin{tabular}{||l|l|l||}
\hline \multicolumn{2}{|c||}{ ArticleInfo } \\
\hline \hline ArticleID & $:$ & 4257 \\
\hline \hline ArticleDOI & $:$ & $10.1186 /$ ccf-2000-6539 \\
\hline \hline ArticleCitationID & $:$ & 6539 \\
\hline \hline ArticleSequenceNumber & $:$ & 45 \\
\hline \hline ArticleCategory & $:$ & Paper Report \\
\hline \hline ArticleFirstPage & $:$ & 1 \\
\hline \hline ArticleLastPage & $:$ & 3 \\
\hline \hline & $:$ & RegistrationDate : 2000-10-12 \\
ArticleHistory & $:$ & OnlineDate \\
\hline \hline ArticleCopyright & $:$ & Current Science Ltd2000-10-12 \\
\hline \hline ArticleGrants & $:$ & \\
\hline \hline ArticleContext & $:$ & 1305433 \\
\hline \hline
\end{tabular}


Aff1 Christiana Hospital Wilmington, Delaware, USA

\section{Keywords}

Gastric tonometry, sepsis, septic shock, systemic hypotension, tissue oxygenation

\section{Comments}

Hypotension and impaired tissue perfusion are major problems in septic shock. Different hemodynamic endpoints have been suggested as goals for resuscitation, often without critical evaluation. One such goal is a target mean arterial pressure (MAP) of $>60 \mathrm{mmHg}$. Below this value, autoregulation in the renal, cardiac and cerebral vasculature fails, resulting in organ ischemia. The authors sought to determine if titrating MAP to levels above $60 \mathrm{mmHg}$ (up to $85 \mathrm{mmHg}$ ) improved indices of tissue perfusion or oxygenation.In this small study it did not. In particular tissue perfusion, as measured by urine output, gastric mucosal $\mathrm{pCO}_{2}$, and skin red blood cell ( $\mathrm{RBC}$ ) flow were unchanged, as was total oxygen consumption. The study was limited by its small size, only 10 patients. In particular, only three patients had chronic hypertension, and it was these patients who were thought to have potentially altered autoregulation requiring higher than expected MAP for adequate organ perfusion. An additional limitation was that not all the patients received identical vasoactive agents. While all required norepinephrine (NE), others received dopamine and/or dobutamine. This may have resulted in direct drug effects which altered the results. The authors recognize these issues. Nonetheless this limited study does suggest that the current practice of titrating MAP to $>60 \mathrm{mmHg}$ is reasonable and that more rigorous study is needed.

\section{Introduction}

Septic shock is characterized by an elevated cardiac output and systemic vasodilation. In addition to volume expansion, individuals frequently require vasopressors such as norepinephrine or high dose dopamine to maintain an adequate arterial perfusion pressure. The exact endpoints to which such agents should be titrated are not entirely clear. The aim of this study was to investigate the increase in tissue perfusion associated with increasing MAP, brought about by the titration of NE, in septic shock patients.

\section{Methods}


- 10 patients enrolled (for criteria see paper)

- Colloid or crystalloid infusions used to maintain pulmonary artery occlusion pressure (PaOP) $>12$ $\mathrm{mmHg}$

- During initial resuscitation, MAP was titrated to $65 \mathrm{mmHg}$ using NE

- Cardiac index(CI), PaOP, heart rate (HR), MAP, urine output, arterial and mixed venous blood gasses, serum lactate and skin RBC flow and velocity were measured

- After titrating MAP to 75 and then $85 \mathrm{mmHg}$, the measurements were repeated

- Values were compared by ANOVA

\section{Results}

Seven men and three women were enrolled - four with pneumonia and three with abdominal foci of infection. Two were anuric on entry; four were receiving dopamine infusions and one dobutamine. With increasing MAP there were significant linear trend increases in CI,systemic vascular resistance index, and oxygen delivery. No other parameter was significantly altered. In particular, indices of tissue perfusion (urine output, gastric mucosal $\mathrm{pCO}_{2}$, and skin $\mathrm{RBC}$ flow) were unchanged.

\section{References}

1. LeDoux D, Astiz ME, Carpati C, Rackow E: Effects of perfusion pressure on tissue perfusion in septic shock. Crit Care Med. 2000, 28: 2729-2732. 